\title{
UI AKTIVITAS KAPANG HASIL ISOLASI TANAH GUNUNG MERAPI DAN HUTAN MANGROVE SUWUNG YANG BERPOTENSI SEBAGAI AGEN BIOFERTILIZER PADA BERBAGAI TINGKAT SALINITAS
}

\author{
Heri Susanto ${ }^{1}$, Suhartono ${ }^{1}$, dan I Made Sudiana ${ }^{2}$ \\ ${ }^{1}$ Fakultas Matematika Ilmu Pengetahuan Alam Universitas Negeri Jakarta, Jl. Pemuda No. 10 Rawamangun \\ 13220. Indonesia \\ ${ }^{2}$ Puslit Biologi LIPI, JI Raya Bogor Km 46 Cibinong
}

\begin{abstract}
Abstrak
Penelitian ini bertujuan untuk memperoleh informasi aktivitas kapang yang berpotensi sebagai Agen biofertilizer yang tahan terhadap kondisi salin. Kapang yang digunakan merupakan hasil isolasi dari tanah lereng Gunung Merapi (GM) dan tanah daerah Hutan Mangrove Suwung (MS). Kapang GM dan MS diuji kemampuannya dalam menghasilkan enzim amilase, selulase dan fosfatase serta kemampuannya dalam menghasilkan fosfat terlarut dan hormon pertumbuhan IAA pada medium dengan variasi kadar $\mathrm{NaCl} 0 \%, 2 \%$, 5\%, 10\% dan 20\%. Enzim amilase optimum yang dihasilkan oleh kapang GM adalah 8,783 mmol/jam dan pada kapang MS adalah 11,417 mmol/jam, enzim selulase optimum yang dihasilkan oleh kapang GM adalah 0,144 $\mathrm{mmol} / \mathrm{jam}$ dan pada kapang MS adalah 0,983 mmol/jam, enzim fosfatase optimum yang dihasilkan oleh kapang GM adalah 0,587 mmol/jam dan pada kapang MS adalah 0,604 mmol/jam, fosfat terlarut optimum yang dihasilkan kapang GM adalah 84,857 ppm dan pada kapang MS adalah 70,352 ppm, hormon IAA optimum yang dihasilkan kapang GM adalah 0,223 ppm dan pada kapang MS adalah 0,510 ppm. Penelitian ini menunjukkan bahwa Kapang GM cenderung lebih tahan terhadap kondisi salin sehingga lebih efektif digunakkan sebagai komponen biofertilizer pada daerah dengan salinitas yang relatif tinggi.
\end{abstract}

Kata kunci : Kapang, Biofertilizer, Salinitas

Abstrack

This study aims to obtain information of potentially mold activity as Agent Biofertilizer that are resistant to saline conditions. Mold that is used is the result of isolation from the ground slopes of Mount Merapi (GM) and land area Suwung Mangrove Forest (MS). GM mold and MS tested for their ability to produce the enzyme amylase, cellulase and phosphatase and the ability to produce soluble phosphate and growth hormone IAA in the medium with variations in levels of $\mathrm{NaCl} 0 \%, 2 \%, 5 \%, 10 \%$ and $20 \%$. Optimum amylase enzyme produced by GM mold is $8.783 \mathrm{mmol} / \mathrm{h}$ and the MS mold is $11.417 \mathrm{mmol} / \mathrm{h}$, optimum cellulase enzymes produced by GM mold is $0.144 \mathrm{mmol} / \mathrm{h}$ and the MS mold is $0.983 \mathrm{mmol} / \mathrm{h}$, the optimum enzyme phosphatase produced by GM mold is $0.587 \mathrm{mmol} / \mathrm{h}$ and the MS mold is $0.604 \mathrm{mmol} / \mathrm{h}$, optimum dissolved phosphate produced by GM mold is $84.857 \mathrm{ppm}$ and MS mold is $70.352 \mathrm{ppm}$, optimum IAA hormone produced by GM mold is 0.223 ppm and the MS mold is 0.510 ppm. This study shows that GM mold tend to be more resistant to saline conditions so that more effective as a component Biofertilizer in areas with relatively high salinity.

Key Word : Mold, Biofertilizer, Salinity

\section{Pendahuluan}

Pemanasan global memacu melelehnya es di kutub bumi sehingga permukaan air laut meningkat, hal ini mengakibatkan dataran yang lebih rendah akan tenggelam dan tekanan air laut ke daratan meningkat. Secara tidak langsung dapat mempengaruhi kadar salinitas yang terdapat di daratan, yang nantinya akan mempengaruhi kondisi mikroba tanah tersebut dimana kadar salinitas yang tinggi menyebabkan cairan didalam sel mikroba tersebut keluar hingga mengalami kekeringan dan akhirnya mikroba tersebut lisis. Hal ini dapat berpengaruh terhadap produktivitas tanah dan dikhawatirkan akan mendatangkan masalah baru bagi kelangsungan produksi pertanian, terutama tanaman pangan $[1,2]$. Untuk mengatasi dampak perubahan lingkungan akibat pemanasan global perlu dilakukan langkah pencegahan, salah satunya dengan aplikasi teknologi biofertilizer dengan kandungan mikroba fungsional yang tahan terhadap 
salinitas. Teknologi biofertilizer sepuluh tahun ke depan akan menjadi tulang punggung kemajuan sektor pertanian khususnya pertanian organik di Indonesia. Teknologi biofertilizer dapat dilakukan melalui pendekatan baik pupuk organik maupun pupuk hayati [3]. Kedua pendekatan tersebut menggunakan mikroba tanah sebagai kunci optimasi proses mineralisasi dan stimulasi pertumbuhan tanaman.

Mikroba tanah dipandang sangat penting sehingga menjadi salah satu indikator dalam menentukan indeks kualitas tanah. Mikroba tanah diketahui mempunyai peranan penting sebagai komponen teknologi pertanian melalui berbagai proses antara lain dekomposisi bahan organik, mineralisasi senyawa organik, fiksasi hara dan pelarut hara [4]. Hal tersebut tidak lepas dari kemampuan mikroba tersebut dalam menghasilkan enzim amilase, selulase dan fosfatase.

Contoh mikroba yang berperan penting dalam biofertilizer adalah dari kelompok kapang. Berbagai spesies kapang seperti Penicillium, Fusarium, dan Aspergillus diketahui berpotensi tinggi sebagai agen biofertilizer dalam peranannya melarutkan fosfat terikat menjadi fosfat yang tersedia dalam tanah.

Penggunaan mikroba pelarut fosfat merupakan salah satu pemecahan masalah peningkatan efisiensi pemupukan fosfat yang aman lingkungan, yang sekaligus dapat menghemat penggunaan pupuk fosfat [5].

Penelitian mengenai kapang yang berpotensi sebagai agen biofertilizer sudah banyak dilakukan namun belum banyak informasi mengenai pengaruh salinitas terhadap aktivitas kapang dalam peranannya sebagai agen biofertilizer.

Oleh karena itu perlu dilakukan penelitian mengenai aktivitas kapang yang berpotensi sebagai agen biofertilizer pada berbagai tingkat salinitas. Selain itu, hasil dari penelitian ini dapat membantu memaksimalkan pemanfaatan kapang juga melengkapi informasi ilmiah yang dapat digunakan untuk penelitian lebih lanjut.

\section{Metodologi Penelitian}

\section{Alat dan Bahan}

Peralatan yang digunakan adalah botol sampel, microtube Eppendorf sentrifuse $\mathrm{H}-15$ FR Kokusan, mikropipet pipetpal, Laminar Air Flow Sanyo Bioclean Bench, Alat pemanas, kuvet, spektrofotometer Mapada V 1100D, bioshaker incubator BR-300 LF, bioshaker BR$23 \mathrm{FP}$, tabung reaksi bertutup $10 \mathrm{~mL}$ Iwaki, rak tabung reaksi, alat vortex Shibasta TTM-1, Hot plate IKA RH Basic 2, gelas kimia $100 \mathrm{~mL}$ pyrex, botol aquadest, autoclave Tomy SX-500, inkubator Sanyo, cawan petri, spatula, labu Erlenmeyer $250 \mathrm{~mL}$ Pyrex, gelas ukur $100 \mathrm{~mL}$, stopwatch DT20-501Y, neraca Sartorius, pipet tetes.

Bahan-bahan yang digunakan adalah isolat kapang yang disolasi dari Gunung Merapi pasca erupsi dan Hutan Mangrove Suwung Bali, CMC BD Company, PDA, PDB, Starch Merck, DNS Sigma, alkohol 70\%, $\mathrm{K}_{2} \mathrm{HPO}_{4}$ Merck, $\mathrm{KH}_{2} \mathrm{PO}_{4}$ Merck, $\left(\mathrm{NH}_{4}\right)_{2} \mathrm{SO}_{4}$ Merck, $\mathrm{MgSO}_{4} .7 \mathrm{H}_{2} \mathrm{O}$ Merck, glukosa C.V Prima Darmala, agar C.V Prima Darmala, $\mathrm{FeCl}_{3} .6 \mathrm{H}_{2} \mathrm{O}$ Merck, $\quad \mathrm{Ca}_{3}\left(\mathrm{PO}_{4}\right)_{2}$, triptofan Merck, $\mathrm{MgCl}_{2} .7 \mathrm{H}_{2} \mathrm{O}, \mathrm{FeSO}_{4} .7 \mathrm{H}_{2} \mathrm{O}$ Wako, yeast extract BD Company, fenil fosfat Merck, Merck, NaCl, $\mathrm{H}_{2} \mathrm{SO}_{4}$ Merck, $\left(\mathrm{NH}_{4}\right)_{6} \mathrm{Mo}_{7} \mathrm{O}_{24} \cdot 4 \mathrm{H}_{2} \mathrm{O}$ Merck, asam askorbat Merck, $\mathrm{K}(\mathrm{SbO}) \cdot \mathrm{C}_{4} \mathrm{H}_{4} \mathrm{O}_{6} \frac{1}{2} . \mathrm{H}_{2} \mathrm{O}$ Merck, $\mathrm{NaOH}, \mathrm{KCl}$ Wako.

\section{Cara Kerja}

\section{a. Uji Aktivitas Enzim Amilase}

Penentuan aktivitas enzim amilase dilakukan dengan cara biakan kapang yang telah ditumbuhkan pada medium amilum cair pada berbagai variasi salinitas yaitu $0 \%, 2 \%$, $5 \%, 10 \%$ dan $20 \% \mathrm{NaCl}$ dipipet sebanyak $1 \mathrm{~mL}$ lalu dimasukkan ke dalam tabung eppendorf 

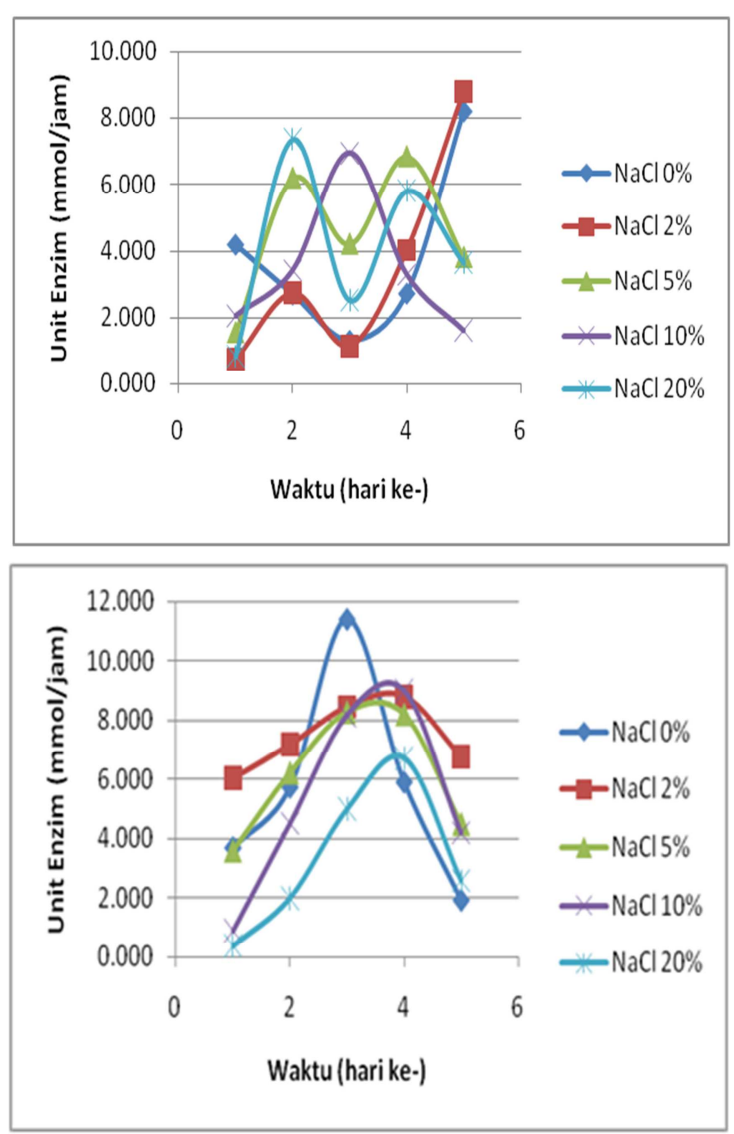

Gambar 1. Grafik Aktivitas Enzim Amilase (a) Enzim Amilase yang Dihasilkan oleh Kapang GM (b) Enzim Amilase yang Dihasilkan oleh Kapang MS

dan disentrifugasi selama 5 menit dengan kecepatan $6000 \mathrm{rpm}$ suhu $4^{\circ} \mathrm{C}$. Sebanyak 500 $\mu \mathrm{L}$ supernatan dimasukkan dalam tabung reaksi dan ditambahkan $500 \mu \mathrm{L}$ substrat amilum. Kemudian diinkubasi dalam bioshaker $37^{\circ} \mathrm{C}$ selama 1 jam. Setelah 1 jam, ditambahkan $200 \mu \mathrm{L}$ DNS, dan dipanaskan selama 7 menit dalam air mendidih. Reaksi positif ditandai dengan perubahan warna menjadi merah bata. Aktivitas amilase diukur menggunakan spektrofotometer dengan panjang gelombang $540 \mathrm{~nm}$.

\section{b. Uji Aktivitas Enzim Selulase}

Penentuan aktivitas enzim selulase dilakukan dengan cara biakan kapang yang telah ditumbuhkan pada medium CMC cair pada berbagai variasi salinitas yaitu $0 \%, 2 \%$, $5 \%, 10 \%$ dan $20 \% \mathrm{NaCl}$ dipipet sebanyak $1 \mathrm{~mL}$ lalu dimasukkan ke dalam tabung eppendorf dan disentrifugasi selama 5 menit dengan kecepatan $6000 \mathrm{rpm}$ suhu $4^{\circ} \mathrm{C}$. Sebanyak 500 $\mu \mathrm{L}$ supernatan dimasukkan dalam tabung reaksi dan ditambahkan $500 \mu \mathrm{L}$ substrat CMC $1 \%$. Kemudian diinkubasi dalam bioshaker $37^{\circ} \mathrm{C}$ selama 1 jam. Setelah 1 jam, ditambahkan $200 \mu \mathrm{L}$ DNS, dan dipanaskan selama 7 menit dalam air mendidih. Reaksi positif ditandai dengan perubahan warna menjadi merah bata. Aktivitas selulase diukur menggunakan spektrofotometer dengan panjang gelombang $540 \mathrm{~nm}$

\section{c. Uji Aktivitas Enzim Fosfatase}

Penentuan aktivitas enzim fosfatase dilakukan dengan cara biakan kapang yang telah ditumbuhkan pada medium Pikovskaya cair pada berbagai variasi salinitas yaitu $0 \%$, $2 \%, 5 \%, 10 \%$ dan $20 \% \mathrm{NaCl}$ dipipet sebanyak 1 $\mathrm{mL}$ lalu dimasukkan ke dalam tabung eppendorf dan disentrifugasi selama 5 menit,

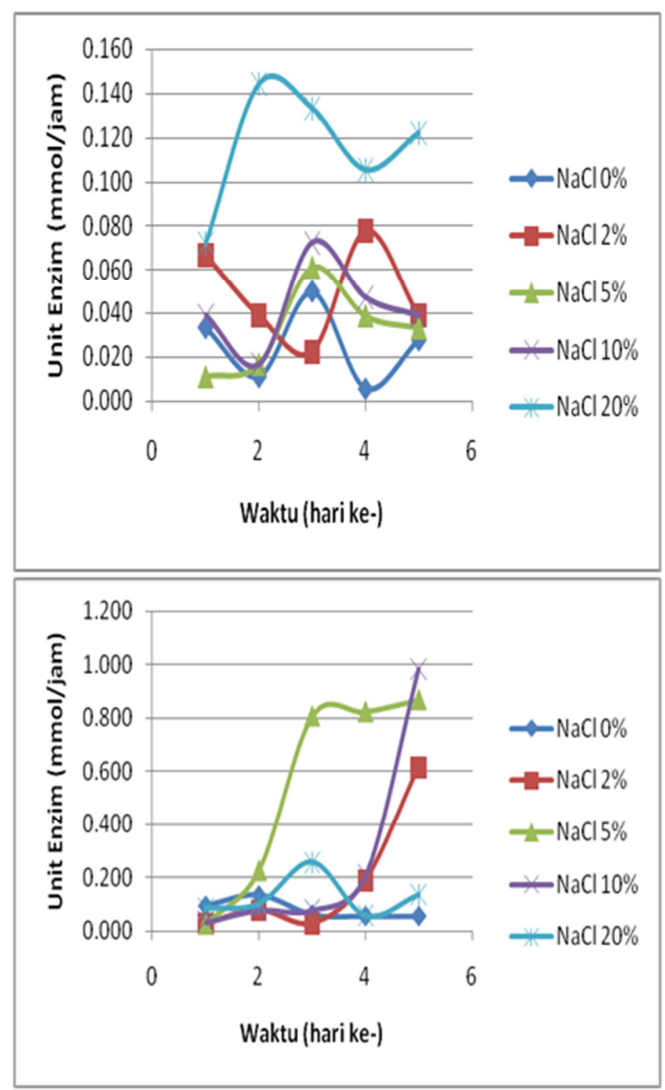

Gambar 2. Grafik Aktivitas Enzim Selulase (a) Enzim Selulase yang Dihasilkan oleh Kapang GM (b) Enzim Selulase yang Dihasilkan oleh Kapang MS 
dengan kecepatan $6000 \mathrm{rpm}$, suhu $4^{\circ} \mathrm{C}$. Sebanyak $50 \mu \mathrm{L}$ supernatan, $50 \mu \mathrm{L}$ fenil fosfat dimasukkan dalam tabung reaksi dan diinkubasi dalam bioshaker $37^{\circ} \mathrm{C}$ selama 1 jam. Setelah 1 jam, ditambahkan $1 \mathrm{~mL}$ aquadest dan $160 \mu \mathrm{L}$ reagen campuran dan diinkubasi kembali selama 10 menit. Reaksi positif ditandai perubahan warna menjadi biru. Aktivitas fosfatase diukur menggunakan spektrofotometer dengan pajang gelombang $880 \mathrm{~nm}$

\section{d. Pengukuran Fosfat Terlarut}

Pengukuran fosfat terlarut dilakukan dengan cara biakan kapang yang telah ditumbuhkan pada medium Pikovskaya cair pada berbagai variasi salinitas yaitu $0 \%, 2 \%$, $5 \%, 10 \%$ dan $20 \% \mathrm{NaCl}$ dipipet sebanyak $1 \mathrm{~mL}$ lalu dimasukkan ke dalam tabung eppendorf dan disentrifugasi selama 5 menit, dengan kecepatan $6000 \mathrm{rpm}$, suhu $4^{\circ} \mathrm{C}$. Sebanyak 50 $\mu \mathrm{L}$ supernatan, ditambahkan $160 \mu \mathrm{L}$ reagen campuran dan diencerkan dengan $1 \mathrm{~mL}$ akuades lalu di aduk dengan menggunakan vortex. Kemudian diinkubasi selama 10 menit. Reaksi positif ditandai perubahan warna menjadi biru. Aktivitas fosfatase diukur menggunakan spektrofotometer dengan panjang gelombang $880 \mathrm{~nm}$.

\section{e. Pengukuran Hormon Indoleacetic Acid (IAA)}

Pengukuran hormon Indoleacetic Acid (IAA) dilakukan dengan cara biakan kapang yang telah ditumbuhkan dalam medium PDB pada berbagai variasi salinitas yaitu $0 \%, 2 \%, 5 \%$, $10 \%$ dan $20 \% \mathrm{NaCl}$ dipindahkan kedalam medium triptofan, setelah 1 hari inkubasi dipipet sebanyak $2 \mathrm{~mL}$ lalu dimasukkan ke dalam tabung eppendorf dan disentrifugasi selama 5 menit, dengan kecepatan 6000 rpm, suhu $4^{\circ} \mathrm{C}$. Sebanyak $1,5 \mathrm{~mL}$ supernatan ditambahkan $1 \mathrm{~mL}$ reagen salkowsky. Sampel didiamkan selama 30 menit, untuk kemudian di ukur dengan spektrofotometer pada panjang gelombang $530 \mathrm{~nm}$. Adanya perubahan warna menjadi merah jambu pada sampel menunjukan adanya IAA.
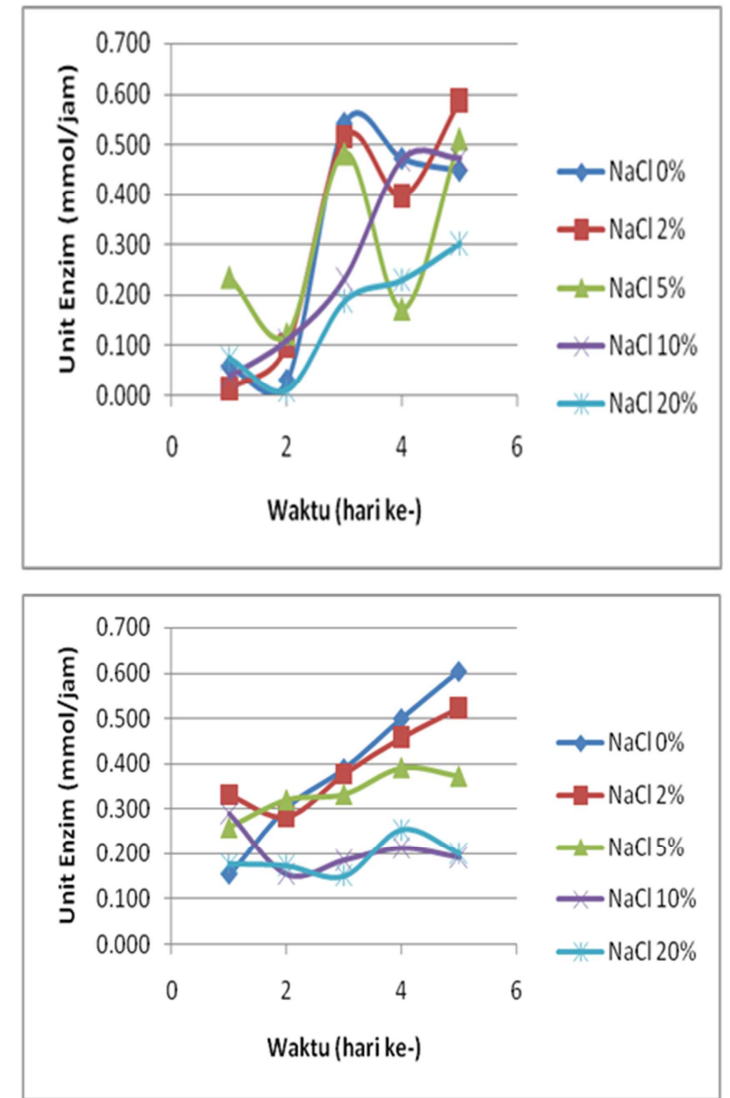

Gambar 3. Grafik Aktivitas Enzim Fosfatase (a) Enzim Fosfatase yang Dihasilkan oleh Kapang GM (b) Enzim Fosfatase yang Dihasilkan oleh Kapang MS

\section{Hasil dan Pembahasan}

a. Uji Aktivitas Enzim Amilase

Dari grafik (Gambar 1b) menunjukkan bahwa salinitas mempengaruhi kapang MS dalam menghasilkan enzim amilase yaitu semakin besar kadar $\mathrm{NaCl}$ yang ditambahkan nilai aktivitas enzim semakin menurun dimana kondisi optimum dalam menghasilkan enzim amilase yaitu tanpa penambahan $\mathrm{NaCl}(\mathrm{NaCl}$ $0 \%)$.

Menurunnya aktivitas enzim karena penambahan kadar $\mathrm{NaCl}$ yang tinggi akan menyebabkan tekanan osmotik yang tidak seimbang sehingga menyebabkan sel kapang mengalami kekeringan dan lisis sehingga lambat laun akan mati [2]. Hal tersebut secara langsung akan menurunkan aktivitas enzim amilase yang dihasilkan. 

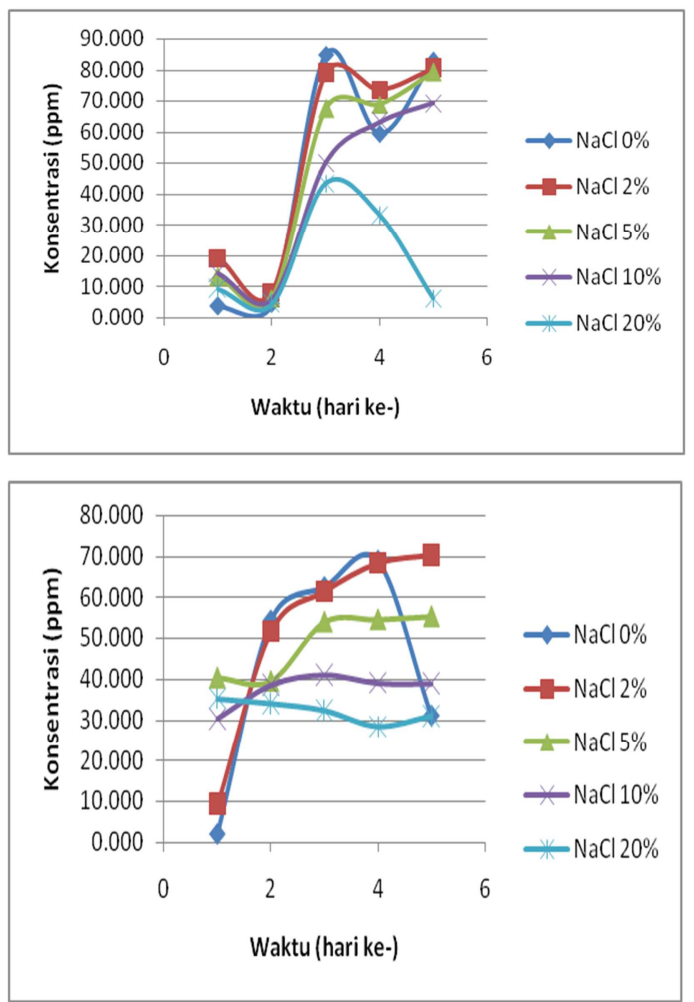

Gambar 4. Grafik Pengukuran Fosfat Terlarut (a) Fosfat Terlarut yang dihasilkan oleh Kapang GM (b) Fosfat Terlarut yang Dihasilkan oleh Kapang MS

Sedangkan grafik pada kapang GM (Gambar 1a) salinitas tidak berpengaruh dalam menghasilkan enzim amilase karena penambahan $\mathrm{NaCl}$ pada kadar 2\% hingga $20 \%$ tidak menurunkan aktivitas enzim amilase. Hal ini karena kapang tersebut memiliki mekanisme khusus untuk beradaptasi pada kondisi salt stress. Kemampuan untuk menjalankan mekanisme adaptasi pada kondisi salt stress mengakibatkan batas toleransi salinitas yang berbeda-beda pada setiap jenis isolat [6].

\section{b. Aktivitas Enzim Selulase}

Berdasarkan hasil pengukuran (Gambar 2) diketahui bahwa kapang GM dan kapang MS mampu menghasilkan enzim selulase pada berbagai tingkat salinitas walaupun dalam jumlah yang sedikit. Dalam menghasilkan enzim selulase kapang MS mempunyai kemampuan yang lebih besar dibandingkan kapang GM dimana kapang MS mampu menghasilkan aktivitas enzim terbesar yaitu $0,983 \mathrm{mmol}$ perjam pada kadar $\mathrm{NaCl} 10 \%$ sedangkan aktivitas enzim terbesar kapang GM hanya 0,144 mmol perjam pada kadar $\mathrm{NaCl} 20 \%$

Berdasarkan hasil pengukuran menunjukkan bahwa terdapat perbedaan kemampuan dalam menghidrolisis selulosa dari masing-masing kapang. Menurut Pelczar dan Chan $^{7}$ (1986), perbedaan kemampuan dalam menghidrolisis selulosa dipengaruhi oleh kemampuan suatu organisme dalam menyintesis enzim yang spesifik. Untuk menyintesis suatu enzim yang spesifik, suatu organisme harus mempunyai gen struktural untuk itu pada kromosomnya. Gen struktural menentukan struktur enzim dalam hal urutan asam-asam aminonya.

\section{c. Aktivitas Enzim Fosfatase}

Berdasarkan grafik (Gambar 3a) diketahui bahwa kapang GM dapat menghasilkan aktivitas enzim optimum pada hari ke-5 sebesar $0,587 \mathrm{mmol}$ perjam yaitu pada penambahan $\mathrm{NaCl}$ sebesar 2\%. Dari data tersebut dapat disimpulkan bahwa penambahan $\mathrm{NaCl}$ sebesar $2 \%$ merupakan batas toleransi salinitas untuk kapang GM dalam menghasilkan enzim fosfatase terbesar dimana untuk penambahan $\mathrm{NaCl}$ diatas $2 \%$ enzim fosfatase yang dihasilkan akan semakin kecil

Berdasarkan Grafik (Gambar 3b) diketahui bahwa penambahan $\mathrm{NaCl}$ menghambat kapang MS dalam menghasilkan enzim fosfatase yaitu semakin banyak $\mathrm{NaCl}$ yang ditambahkan akan semakin menurunkan nilai aktivitas enzim fosfatase yang dihasilkan walaupun penurunannya tidak terlalu signifikan dimana aktivitas enzim fosfatase terendah dihasilkan pada penambahan $\mathrm{NaCl}$ tertinggi ( $\mathrm{NaCl} 20 \%$ ) yang hanya mampu menghasilkan enzim dibawah 0,3 $\mathrm{mmol}$ perjam sedangkan aktivitas enzim optimum yang dihasilkan kapang MS sebesar 0,604 
mmol perjam yaitu tanpa penambahan $\mathrm{NaCl}$ ( $\mathrm{NaCl} 0 \%)$.

Menurunnya aktivitas enzim karena penambahan kadar $\mathrm{NaCl}$ yang tinggi akan menyebabkan tekanan osmotik yang tidak seimbang sehingga menyebabkan sel kapang mengalami kekeringan dan lisis sehingga lambat laun akan mati [2]. Hal tersebut secara langsung akan menurunkan aktivitas enzim fosfatase yang dihasilkan.

\section{d. Fosfat Terlarut}

Berdasarkan hasil pengukuran (Gambar 4) diketahui bahwa kapang GM dan kapang MS mampu melarutkan fosfat pada berbagai tingkat salinitas. Penambahan $\mathrm{NaCl}$ baik pada kapang GM maupun kapang MS akan menurunkan kadar fosfat terlarut yang dihasilkan. Menurunnya aktivitas enzim karena penambahan kadar $\mathrm{NaCl}$ yang tinggi akan menyebabkan tekanan osmotik yang tidak seimbang sehingga menyebabkan sel kapang mengalami kekeringan dan lisis sehingga lambat laun akan mati [2]. Hal tersebut secara langsung akan menurunkan jumlah fosfat yang terlarut.

Dari data aktivitas enzim fosfatase dan fosfat terlarut (Gambar 3 dan Gambar 4) diketahui bahwa pola grafik antara aktivitas enzim fosfatase dengan fosfat terlarut hampir sama karena aktivitas enzim fosfatase merupakan indikator mikroba dalam kemampuannya melarutkan fosfat yaitu jika enzim fosfatase yang dihasilkan besar maka fosfat terlarut yang dihasilkan juga besar.

\section{e. Hormon Indoleacetic Acid}

Berdasarkan grafik (Gambar 5) diketahui bahwa penambahan $\mathrm{NaCl}$ tidak menghambat atau menurunkan kemampuan kapang GM maupun MS dalam menghasilkan hormon IAA dimana pada kapang GM hormon IAA tertinggi dihasilkan pada penambahan $\mathrm{NaCl}$ sebesar $10 \%$ yaitu pada hari ke-4 sebesar 0,223 ppm sedangkan pada kapang MS hormon IAA tertinggi dihasilkan pada penambahan $\mathrm{NaCl}$ sebesar 5\% juga pada hari ke-4 sebesar 0,510 ppm Hal ini karena kapang tersebut memiliki mekanisme khusus untuk beradaptasi pada kondisi salt stress. Kemampuan untuk menjalankan mekanisme adaptasi pada kondisi salt stress mengakibatkan batas toleransi salinitas yang berbeda-beda pada setiap jenis isolat [6].

'Berdasarkan grafik (Gambar 5) diketahui juga bahwa hormon IAA optimum pada berbagai salinitas baru terjadi pada hari ke-4 baik pada kapang GM maupun MS. Hal tersebut dimungkinkan bahwa energi yang terbentuk sebagian digunakan terlebih dahulu untuk pembentukan biomassa sebelum memproduksi hormon IAA secara utuh.
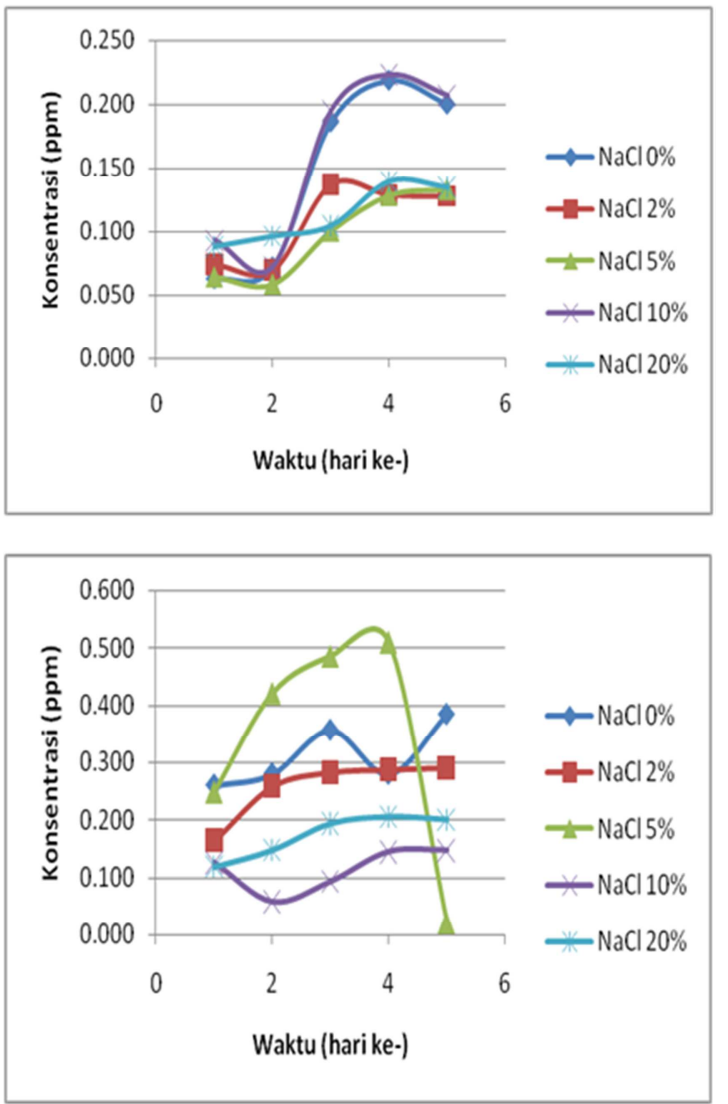

Gambar 5. Grafik Hormon Pertumbuhan IAA (a) Hormon Pertumbuhan IAA yang Dihasilkan oleh Kapang GM (a) Hormon Pertumbuhan IAA yang Dihasilkan oleh Kapang MS 


\section{Kesimpulan Dan Saran}

Kesimpulan

Kapang GM cenderung lebih toleran terhadap salinitas karena adanya penambahan $\mathrm{NaCl}$ tidak menurunkan aktivitas kapang tersebut, berbeda halnya dengan kapang MS dimana semakin besar kadar $\mathrm{NaCl}$ aktivitas kapang tersebut akan semakin menurun.

Saran

Perlu dilakukan pencarian mikroba potensial selain kapang yang toleran terhadap salinitas dengan aktivitas yang lebih besar untuk diaplikasikan langsung ketanaman.

\section{Ucapan Terima Kasih}

Terima kasih kepada Allah SWT yang telah memberikan segalanya pada penulis, kedua orang tua, Drs. Suhartono, M.Kes., Prof Dr I Made Sudiana, M.Sc., Kepala bidang Mikrobiologi dan seluruh staf Puslit Mikrobiologi LIPI yang telah banyak membantu.

\section{Daftar Pustaka}

[1] Sari, N.A., Fauziah, R.N. dan Nurbaety, A.T. 2009. Pengaruh Suhu dan Salinitas terhadap Viabilitas Bakteri Aeromonas hydrophila dan Bacillus sp. Bogor : IPB.

[2] Wichern, J., Wichern, F. and Joergensen, R.G. 2006. Impact of Salinity on Soil Microbial Communities and the Decomposition of Maize in Acidic Soil. Geoderma. 137: 100-108.

[3] Simanungkalit, R.D.M. 2006. Prospek Pupuk Organik dan Hayati. Balai Besar Litbang Sumberdaya Lahan Pertanian. Dalam: Simangungkalit, R.D.M., Suriadikarta, D.A., Saraswati, R., Setyorini, D. \& Hartatik, W. (eds.). 2006. Pupuk Organik dan Pupuk Hayati: Organic Fertilizer and Biofertilizer. Balai Penelitian dan Pengembangan Pertanian: iii +283 hal.

[4] Karlen D.L., Hurley, E.G. and Mallarino, A.P. 2006. Crop Rotation on Soil Quality at Three Northern Corn/Soybean Belt Location. Agron. J. 98:484-495.

[5] Saraswati, R. 1999. Teknologi Pupuk Mikroba Multiguna Menunjang Keberlanjutan Sistem Produksi Kedelai. Jurnal Mikrobiologi Indonesia. 4(1):1-9.

[6] Petrovic, A., Gunde-Cimerman, N. and Plemenitas, A. 1999. Salt stress Affects Sterol Biosynthesis in the Halophilic Black Yeast Hortaea Werneckii. FEMS Microbiology Letters 180 (1999) 325-330.

[7] Pelczar, M.J. dan Chan, E.C.S. 1986. Dasar-dasar Mikrobiologi I. Jakarta : UI Press. 